\title{
Upaya Meningkatkan Hasil Belajar Siswa Melalui Strategi Pembelajaran Permainan Angka Tertempel di SD Inpres 3 Tolai
}

\author{
I Wayan Suada \\ SD Inpres 3 Tolai, Kabupaten Parigi Mautong - Provinsi Sulawesi Tengah \\ Corresponding Author. Email: wayansuada.tolai@gmail.com
}

\begin{abstract}
The purpose of this study was to improve student learning outcomes Article History 4 (four) stages, namely planning, acting, observing, and reflecting. The subjects of this study were Grade VI students of SD Inpres 3 Tolai in the 2020/2021 school year. Data collection techniques using tests, observation, and documentation. The data analysis technique used in this research was qualitative and quantitative Key Words: 67.31, and the second cycle increased to 83.97. While the increase in student learning outcomes that have met the completeness value, namely pre-cycle by $50 \%$. In the first cycle it increased, namely to be $79.17 \%$ and increased again in the second cycle to $100 \%$.

Abstrak: Tujuan dalam penelitian ini adalah untuk meningkatkan hasil belajar siswa tentang hitung campuran dalam proses pembelajaran matematika menggunakan strategi pembelajaran permainan angka tertempel. Penelitian ini menggunakan metode penelitian tindakan kelas yang dilaksanakan dalam 2 (dua) siklus. Masing-masing siklus dilaksanakan dalam 4 (empat) tahap, yaitu perencanaan, tindakan, observasi, dan refleksi. Subyek penelitian ini adalah siswa kelas VI SD Inpres 3 Tolai tahun pelajaran 2020/2021. Teknik pengumpulan data menggunakan tes, observasi, dan dokumentasi. Teknik analisis data penelitian ini menggunakan analisis deskriptif kualitatif dan kuantitatif. Berdasarkan hasil penelitian ini diketahui bahwa peningkatan keaktifan siswa, rata-rata pra siklus 49,68. Pada siklus I mengalami peningkatan menjadi 67,31, dan siklus II mengalami peningkatan lagi menjadi 83,97 . Sementara peningkatan hasil belajar siswa yang sudah memenuhi nilai ketuntasan, yaitu pra siklus sebesar 50\%. Pada siklus I mengalami peningkatan, yaitu menjadi 79,17\% dan meningkat lagi pada siklus II menjadi $100 \%$.
\end{abstract} about mixed arithmetic in the Mathematics learning process using learning Received: 29-01-2021 strategies through sticky numbers games. This study uses a classroom action Revised: 09-03-2021 research method which is carried out in 2 (two) cycles. Each cycle is carried out in Published: 04-04-2021 descriptive analysis. Based on the results of this study, it is known that the increase Learning Outcomes, in student activity, the pre-cycle average is 49.68. In the first cycle it increased to Sticky Numbers Games.

Sejarah Artikel

Diterima: 29-01-2021

Direvisi: 09-03-2021

Diterbitkan: 04-04-2021

Kata Kunci:

Hasil Belajar, Permainan

Angka Tertempel.

How to Cite: Suada, I. (2021). Upaya Meningkatkan Hasil Belajar Siswa Melalui Strategi Pembelajaran Permainan Angka Tertempel di SD Inpres 3 Tolai. Jurnal Paedagogy, 8(2). doi:https://doi.org/10.33394/jp.v8i2.3480

d.

https://doi.org/10.33394/jp.v8i2.3480

This is an open-access article under the CC-BY-SA License.

\section{Pendahuluan}

Salah satu upaya untuk meningkatkan mutu pendidikan adalah dengan cara memperbaiki proses belajar mengajar. Belajar mengajar pada dasarnya adalah interaksi atau hubungan timbal balik antara guru dan siswa dalam situasi pendidikan. Oleh karena itu, guru dalam mengajar dituntut kesabaran, keuletan dan sikap terbuka di samping kemampuan dalam situasi belajar mengajar yang lebih aktif. Belajar merupakan kegiatan utama dari keseluruhan proses pendidikan di sekolah yang bertujuan untuk menghasilkan perubahan tingkah laku. Perubahan itu meliputi kognitif, afektif dan psikomotor (Nurhayati dkk, 2020; Suharni, 2021). Kegiatan pembelajaran memerlukan keaktifan belajar, partisipasi 
dan komunikasi interaktif antara guru dan siswa. Aktivitas belajar dirancang sedemikian rupa sehingga menghasilan pembelajaran yang di tentukan. Keberhasilan dalam proses pembelajaran dapat dilihat dari pemahaman konsep, penguasaan materi dan prestasi belajar (Suarni dkk, 2021; Selamet, 2020; Zainuri, 2020).

Guru sebagai pengajar lebih menekankan pada pelaksanaan tugas merencanakan, melaksanakan proses belajar mengajar, dan menilai hasilnya. Untuk melaksanakan tugas ini, di samping harus menguasai materi atau bahan yang akan diajarkan juga dituntut untuk memiliki seperangkat pengetahuan dan keterampilan teknis mengajar. Sehubungan dengan tanggung jawab profesional dalam melaksanakan tugas mengajar ini, guru dituntut untuk selalu mencari gagasan-gagasan baru (inovasi), berusaha menyempurnakan pelaksanaan tugas mengajar, mencoba bermacam-macam metode dalam mengajar dan mengupayakan pembuatan serta penggunaan alat peraga dalam mengajar (Daryanto, 2010).

Dalam proses belajar mengajar, guru tidak hanya menyampaikan materi namun juga guru harus bisa secara maksimal menyampaikan apa isi dari materi yang diajarkan dalam mata pelajaran Matematika. Selain itu, tugas guru juga harus mampu menyampaikan materi dengan menggunakan suatu metode atau juga strategi pembelajaran yang mampu menciptakan suasana belajar yang ceria, menyenangkan, dan juga siswa mampu memahami materi yang disampaikan. Jika guru tidak mampu menyampaikan materi dengan baik dapat menimbulkan ketidakpahaman dan kebosanan bagi siswa dalam menerima materi yang disampaikan.

Menurut Sanjaya (2008) peran guru menjadi kunci keberhasilan dalam pendidikan dan pembelajaran di sekolah. Selain mengajar, guru juga bertanggung jawab mengatur, mengarahkan, menciptakan kondisi pelajaran yang kondusif di kelas. Berdasarkan pendapat para pakar bahwa para guru sangat penting perannya dalam keberhasialan proses pembelajaran, guru juga sebagai fasilitator serta motivator siswa. Jadi peran guru tidak hanya memberikan pengetahuan melainkan lebih dari itu. Guru sangat berperan penting dalam mengawal dan membimbing siswa untuk mencapai keberhasilan dalam meraih hasil belajar siswa yang maksimal (Irni, 2016; Yuliati 2018).

Berkaitan dengan masalah media, di SD SD Inpres 3 Tolai, sarana dan prasarana sekolah masih kurang. Misalnya masih terbatasnya jumlah LCD proyektor, sehingga tidak setiap mata pelajaran dapat menggunakan media LCD dalam menunjang proses pembelajaran di kelas. Untuk dapat menggunakan media ini harus bergantian dengan mata pelajaran lain dan tidak semua guru mampu menggunakan media ini. Selain itu, penggunakan perpustakaan sekolah masih kurang. Hal ini dapat dilihat pada semakin menurunnya siswa meminjam buku-buku Matematika di perpustakaan sebagai sumber belajar.

Masalah kedua berkaitan dengan konsentrasi siswa dalam mengikuti proses pembelajaran. Menurut Sardiman (2007) konsentrasi dimaksudkan memusatkan segenap kekuatan perhatian pada situasi belajar. Di dalam belajar, mungkin juga ada perhatian sekedarnya tetapi tidak konsentrasi, makna materi yang masuk dalam pikiran mempunyai kecenderungan berkesan tetapi tidak cukup kuat untuk membuat kesan yang hidup dan tahan lama. Selain konsentrasi berkurang, siswa juga memiliki sifat lupa. Hasil pengamatan dari observasi awal menunjukkan, bahwa sehari sesudah para siswa mempelajari suatu bahan pelajaran atau mendengarkan suatu ceramah mereka banyak melupakan apa yang telah mereka peroleh selama jam pelajaran tersebut.

Masalah ketiga yang ditemukan adalah yang berhubungan dengan guru sebagai salah satu sumber dalam mengajar. Pada dasarnya proses pembelajaran Matematika di SD Inpres 3 Tolai masih bersifat konvesional. Pada observasi pembelajaran yang dilakukan oleh guru 
lebih menekankan pada penggunaan metode ceramah. Metode ceramah meminimalkan keterlibatan siswa dalam proses pembelajaran, sehingga guru terlihat lebih aktif dibandingkan dengan siswa. Kebiasaan bersikap pasif dalam proses pembelajaran dapat mengakibatkan sebagian besar siswa takut dan malu bertanya kepada guru mengenai materi yang kurang dipahami. Suasana belajar di kelas menjadi sangat monoton dan kurang menarik. Cara ini cukup membosankan, maka dalam pelaksanaannya memerlukan metode/strategi tertentu agar gaya penyajiannya tidak membosankan namun menarik perhatian siswa.

Memperhatikan hal tersebut, perlu kiranya diambil tindakan untuk meningkatkan keaktifan belajar, sehingga hasil belajar Matematika siswa kelas VI juga ikut meningkat. Oleh karena itu, perlu dilakukan perbaikan dalam proses belajar-mengajar dengan penelitian tindakan kelas. Penelitian tindakan kelas merupakan suatu pencermatan terhadap kegiatan belajar berupa sebuah tindakan, yang sengaja dimunculkan dan terjadi dalam sebuah kelas secara bersama (Arikunto, 2009). Dengan melaksanakan tahapan- tahapan dalam PTK, guru akan mampu memperbaiki proses pembelajaran melalui suatu kajian yang dalam terhadap apa yang terjadi dikelasnya. Tindakan yang dilakukan guru semata-mata didasarkan pada masalah aktual dan faktual yang berkembang di kelas.

Agar hal tersebut bisa diminimalkan dan tujuan pembelajaran Matematika dapat tercapai maka diperlukan suatu strategi khusus dari guru Matematika agar minat dan keaktifan siswa dalam mengikuti mata pelajaran Matematika lebih tinggi. Upaya membangkitkan kembali keaktifan serta minat siswa terhadap pembelajaran Matematika diperlukan optimalisasi peran guru Matematika di dalam kelas. Seorang guru dalam proses belajar mengajar di kelas tidak hanya sekedar menyampaikan materi pelajaran yang disampaikan menjadi kegiatan yang menyenangkan dan mudah dipahami oleh siswa. Aktivitas guru dan siswa sebagai pelaku utama dalam kegiatan pembelajaran mutlak diperlukan demi tercapainya tujuan belajar. Segala tindakan yang dilakukan guna mencapai tujuan belajar, tersusun sebagai strategi pembelajaran. Hendaknya guru juga dapat mengelola kelas secara efektif dan efisien, antara lain dengan pemilihan strategi pembelajaran yang sesuai dengan materi pembelajaran dan kondisi lingkungan sekolah khususnya kelas.

Dalam proses pembelajaran, guru haruslah mampu mengembangkan potensi yang dimiliki oleh siswa secara maksimal, baik dari ranah kognitif (pengetahuan), ranah afektif (sikap dan nilai), serta ranah psikomotorik (keterampilan). Dengan keterpaduan semua aspek tersenut diharapkan siswa menjadi warga negara yang mempunyai nilai sosial, kritis serta kreatif dalam menyikapi berbagai permasalahan dalam kehidupan bermasyarakat. Untuk mengatasi hal tersebut hendaknya guru Matematika harus mampu mengembangkan materi pelajaran Matematika yang ada dengan cara menggunakan strategi pembelajaran aktif atau menciptakan suatu inovasi pembelajaran yang mampu membuat siswa tertarik terhadap mata pelajaran Matematika.

Strategi pembelajaran ini menuntut peran aktif siswa di dalam kelas, namun seorang guru tetap harus berperan di dalam kelas tersebut, yaitu memberi semangat, dorongan belajar, dan bimbingan terhadap siswa. Dalam setiap strategi pembelajaran memiliki keunggulan masing-masing, begitu pula strategi pembelajaran aktif melalui permainan angka tertempel. Kelebihan strategi pembelajaran melalui permainan angka tertempel yaitu: (1) Siswa lebih berperan aktif karena siswa terlibat di dalam pembelajaran, (2) Terjadi proses interaksi antara guru dan siswa sehingga menguatkan materi yang hendak dipelajari, (3) Siswa lebih mudah mempelajari topik karena pembelajaran dikemas dengan strategi permainan. 
Melalui permainan angka tertempel merupakan sebuah strategi pembelajaran yang membantu siswa untuk mendapat pengetahuan, keterampilan, dan sikap secara aktif serta menjadikan belajar tidak terlupakan (Silberman, 2009). Strategi pembelajaran aktif melalui permainan angka tertempel bisa digunakan sebagai metode alternatif yang dirasa lebih bisa memahami karakteristik belajar peserta didik yang berbeda-beda.

Berdasarkan uraian di atas dapat disimpulkan bahwa penggunaan strategi pembelajaran aktif melalui permainan angka tertempel dapat dijadikan satu strategi yang efektif dan bermanfaat serta berpengaruh untuk meningkatkan hasil belajar siswa pada mata pelajaran Matematika. Adapun tujuan penelitian ini adalah untuk meningkatkan hasil belajar siswa tentang hitung campuran melalui permainan angka tertempel di kelas VI SD Inpres 3 Tolai Semester I Tahun Pelajaran 2020/2021.

\section{Metode Penelitian}

Penelitian ini menggunakan metode penelitian tindakan kelas, yaitu penelitian yang dilakukan oleh guru, bekerja sama dengan peneliti (atau dilakukan oleh guru sendiri yang juga bertindak sebagai peneliti) di kelas atau di sekolah tempat ia mengajar dengan penekanan pada penyempurnaan atau peningkatan proses dan praktis pembelajaran (Arikunto, 2009). Subyek penelitian ini adalah siswa kelas VI SD Inpres 3 Tolai tahun pelajaran 2020/2021 yang berjumlah 24 orang siswa, terdiri dari 15 siswa laki-laki dan 9 siswa perempuan.

Teknik pengumpulan data yang digunakan dalam penelitian ini adalah tes, observasi, dan dokumentasi. Sedangkan teknik analisis datanya menggunakan analisis deskriptif kualitatif dan kuantitatif. Indikator keberhasilan penelitian tindakan kelas ini adalah diharapkan dengan penerapan strategi pembelajaran permainan angka tertempel dapat meningkatkan hasil belajar siswa sekurang-kurangnya $85 \%$ siswa tuntas secara klasikal dan memperoleh skor rata-rata kemampuan $\geq 68$ dalam mengerjakan soal Matematika.

\section{Hasil Penelitian dan Pembahasan Deskripsi Siklus I}

Penelitian tindakan kelas yang telah dilaksanakan ini terdiri dari dua siklus, dalam setiap siklusnya terdiri dari empat tahapan yaitu perencanaan (planning), pelaksanaan (acting), pengamatan (observing), dan refleksi. Adapun kegiatan yang dilakukan dalam proses pembelajaran pada siklus I meliputi tahap perencanaan, pelaksanaan, pengamatan, dan refleksi diuraikan sebagai berikut:

\section{Perencanaan (Planning)}

Pada siklus I guru menyampaikan materi hitung campuran. Dalam tahap perencanaan guru melakukan berbagai langkah yaitu (1) merumuskan tujuan yang hendak dicapai dalam proses pembelajaran dengan menggunakan strategi pembelajaran aktif permainan kartu tertempel. Adapun tujuan tersebut adalah tujuan akademik dan menciptakan suasana belajar yang menyenangkan. Tujuan akademik difokuskan agar siswa dapat meningkatkan hasil belajar siswa dan dapat mencapai kriteria ketuntasan minimal 68 serta ketuntasan klasikal $85 \%$. Tujuan menciptakan suasana pembelajaran yang menyenangkan yaitu diharapkan dengan menggunakan strategi pembelajaran aktif permainan kartu tertempel dapat menarik minat siswa untuk mempelajari Matematika dalam suasana yang menyenangkan dan kerjasama kelompok. (2) guru merencanakan skenario pembelajaran yang berupa rencana perbaikan pembelajaran, (3) guru menyiapkan media berupa kartu index, (4) guru merancang lembar pengamatan keaktifan siswa, dan (4) guru merancang alat evaluasi yang diberikan 
kepada siswa untuk mengukur keberhasilan belajar siswa dalam pembelajaran Matematika dengan menggunakan strategi pembelajaran aktif permainan kartu tertempel.

\section{Pelaksanaan (Acting)}

Kegiatan yang dilakukan guru selama proses pembelajaran pada siklus pertama yaitu mempersiapkan perangkat pembelajaran yang dibutuhkan dan mengkondisikan siswa agar siap mengikuti kegiatan belajar mengajar. Guru memberikan apersepsi sebagai upaya untuk memberikan rangsangan kepada siswa agar lebih siap belajar dengan memberikan beberapa pertanyaan yang berkaitan dengan materi yang akan disampaikan pada pembelajaran siklus I. Selain itu, guru memotivasi siswa dengan penjelasan singkat hitung campuran dengan tanya jawab untuk membentuk suasana interaktif antara guru dan siswa sehingga pembelajaran berlangsung dua arah.

Kegiatan selanjutnya, guru menyampaikan prosedur pelaksanaan strategi pembelajaran aktif permainan kartu tertempel dengan cara membagi secara acak kartu index berupa pertanyaan dan jawaban secara acak kepada siswa. Siswa diberi kesempatan untuk mencari pasangan dari kartu yang telah mereka dapat. Kemudian guru memberi perintah kepada siswa yang bermain mencari tempat duduk bersama. Guru memberi tahu kepada siswa yang bermain untuk tidak memberitahukan isi dari kartu yang dimilikinya. Ketika siswa yang bermain telah menempati tempatnya, guru memerintah setiap pasangan untuk menguji peserta didik lain dengan membaca kertas pertanyaan dengan suara keras dan menantang teman sekelasnya untuk menginformasikan jawaban kepadanya. Siswa yang bisa menjawab pertanyaan yang diujikan membacakan kartu jawaban yang ada dan menunjukkan kartu index yang dimilikinya. Permainan tersebut diulang sampai seluruh siswa mendapatkan pasangannya. Setelah semua pertanyaan serta jawaban dilontarkan dan semua siswa mendapatkan pasangannya, guru memberikan pertanyaan kepada siswa dari permainan yang telah dilakukan sebelumnya. Pada akhir pelaksanaan tindakan siklus I, guru memberikan tes evaluasi siklus I untuk mengukur hasil belajar siswa. Hitung campuran nilai hasil belajar siswa pra siklus dan siklus I dapat dilihat pada tabel berikut ini.

\section{Tabel 1. Hasil Evaluasi Siswa Siklus I}

\begin{tabular}{|c|l|c|c|}
\hline No. & \multicolumn{1}{|c|}{ Keterangan Hasil Tes } & Pra Siklus & Siklus 1 \\
\hline 1 & Jumlah Siswa Kelas VI & 24 & 24 \\
\hline 2 & Nilai Tertinggi & 82 & 92 \\
\hline 3 & Nilai Terendah & 48 & 64 \\
\hline 4 & Nilai Rata-rata & 63,54 & 76,50 \\
\hline 5 & Jumlah Siswa yang Tuntas & 12 & 19 \\
\hline 6 & Jumlah Siswa yang Tidak Tuntas & 12 & 5 \\
\hline 7 & Persentase Ketuntasan & $50 \%$ & $79,17 \%$ \\
\hline 8 & Persentase Ketidaktuntasan Belajar & $50 \%$ & $20,83 \%$ \\
\hline
\end{tabular}

Berdasarkan tabel di atas, diketahui adanya peningkatan hasil belajar sebelum tindakan pada akhir siklus I. Nilai rata-rata da presentase ketuntasan belajar sudah meningkat dari data awal yaitu dari nilai rata-rata dan presentase ketuntasan belajar sudah meningkat dari data awal yaitu dari nilai rata- rata 63,54 menjadi 76,50 dan ketuntasan secara klasikal dari $50 \%$ menjadi $79,17 \%$. Akan tetapi, ketuntasan belajar siklus I hanya mencapai $79,17 \%$ belum memenuhi kriteria indikator keberhasilan ketuntasan klasikal yang telah ditetapkan yaitu $85 \%$ siswa belajar yang tuntas sehingga perlu perbaikan pada siklus berikutnya. 


\section{Pengamatan (Observing)}

Tahapan pengamatan, peneliti mengamati proses pembelajaran yang berlangsung dengan mencatat temuan-temuan yang ada pada lembar pengamatan yang telah tersedia. Ada dua aspek yang peneliti amati dalam proses pembelajaran Matematika dengan menggunakan strategi pembelajaran aktif permainan kartu tertempel yaitu aspek keaktifan siswa dan kinerja guru. Pada siklus I, keaktifan siswa dalam pembelajaran Matematika dengan menggunakan strategi pembelajaran aktif permainan kartu tertempel secara menyeluruh mencapai ratarata $70 \%$. Hal ini kemungkinan diakibatkan para siswa belum begitu jelas dan masih bingung dengan strategi pembelajaran aktif permainan kartu tertempel karena baru pertama kali diterapkan dalam pembelajaran Matematika di kelas VI ini. Berikut perhitungan persentase dan diagram keaktifan siswa. Berdasarkan hasil observasi dan dilakukan analisis data, maka diperoleh data bahwa pada siklus I secara keseluruhan tingkat keaktifan siswa rata-rata mendapatkan skor 67,31 .

\section{Refleksi}

Tahap refleksi merupakan koreksi terhadap tindakan yang telah dilaksanakan untuk mengetahui kelabihan dan kekurangan yang ada pada siklus I. Dari refleksi yang dilaksanakan diperoleh hasil sebagai berikut: (1) masih banyak siswa pasif dalam proses pembelajaran yakni mencapai $70 \%$ sehingga belum mencapai kriteria ketuntasan klasikal yang telah diterapkan yakni $75 \%$ siswa aktif dalam pembelajaran; (2) guru masih canggung dalam menerapkan strategi pembelajaran aktif permainan kartu tertempel. Hal ini memungkinkan siswa masih pasif dalam proses pembelajaran karena baru pertama kali menerapkan strategi pembelajaran ini. Proses pembelajaran di dalam kelas masih didominasi oleh guru. Berdasarkan kekurangan pada siklus I, maka peneliti sebagai observer dan guru sebagai sumber belajar berkolaborasi untuk menyusun rencana tindak lanjut (RTL), dalam perbaikan pada siklus berikutnya. Rencana tindak lanjut tersebut antara lain: (!) Kesiapan siswa untuk membaca materi selanjutnya dengan cara mencari sumber belajar selain buku paket pedoman belajar dan lembar kerja siswa (LKS). (2) Memotivasi siswa untuk lebih percaya diri dalam menyampaikan pendapat, baik dalam hal mengajukan ataupun menjawab pertanyaan di hadapan siswa yang lain serta memberikan reward berupa nilai. (3) Guru harus mampu mengoptimalkan waktu dengan baik dan mengkondisikan siswa secara keseluruhan, agar pelaksanaan strategi pembelajaran aktif permainan kartu tertempel lebih sistematis.

\section{Deskripsi Siklus II}

Dalam pelaksanaan siklus I, indikator penelitian yang telah diterapkan belum tercapai, sehingga dilanjutkan ke siklus II. Adapun kegiatan yang dilakukan dalam proses pembelajaran pada siklus II meliputi tahap perencanaan, pelaksanaan, pengamatan, dan refleksi diuraikan sebagai berikut:

\section{Perencanaan (Planning)}

Pelaksanaan siklus II didasarkan pada siklus I. Sebelum proses pembelajaran pada siklus II dimulai, guru mengkoreksi kekurangan yang ada pada siklus I. Proses pembelajaran pada siklus II, guru berusaha untuk lebih menguasai strategi pembelajaran aktif permainan kartu tertempel dalam penerapannya dapat berjalan dengan baik dan siswa-siswa dapat mengikuti pembelajaran dengan baik. Diharapkan dalam pelaksanaan siklus II suasana pembelajaran lebih menyenangkan dan tidak kaku sehingga keaktifan siswa, interaksi antar guru dan siswa maupun hasil belajarnya dapat meningkat. 


\section{Pelaksanaan (Acting)}

Kegiatan yang dilakukan guru selama proses pembelajaran pada siklus kedua yaitu mempersiapkan perangkat pembelajaran yang dibutuhkan dan mengkondisikan siswa agar siap mengikuti kegiatan belajar mengajar. Guru memberikan apersepsi sebagai upaya untuk memberikan rangsangan kepada siswa agar lebih siap belajar dengan memberikan beberapa pertanyaan yang berkaitan dengan materi yang akan disampaikan pada pembelajaran siklus II. Selain itu, guru memotivasi siswa dengan penjelasan singkat hitung campuran dengan tanya jawab untuk membentuk suasana interaktif antara guru dan siswa sehingga pembelajaran berlangsung dua arah. Kegiatan selanjutnya, guru menyampaikan prosedur pelaksanaan strategi pembelajaran aktif permainan kartu tertempel dengan cara membagi secara acak kartu index berupa pertanyaan dan jawaban secara acak kepada siswa. Siswa diberi kesempatan untuk mencari pasangan dari kartu yang telah mereka dapat. Kemudian guru memberi perintah kepada siswa yang bermain mencari tempat duduk bersama. Guru memberi tahu kepada siswa yang bermain untuk tidak memberitahukan isi dari kartu yang dimilikinya.

Ketika siswa yang bermain telah menempati tempatnya, guru memerintah setiap pasangan untuk menguji peserta didik lain dengan membaca kertas pertanyaan dengan suara keras dan menantang teman sekelasnya untuk menginformasikan jawaban kepadanya. Siswa yang bisa menjawab pertanyaan yang diujikan membacakan kartu jawaban yang ada dan menunjukkan kartu index yang dimilikinya. Permainan tersebut diulang sampai seluruh siswa mendapatkan pasangannya. Setelah semua pertanyaan serta jawaban dilontarkan dan semua siswa mendapatkan pasangannya, guru memberikan pertanyaan kepada siswa dari permainan yang telah dilakukan sebelumnya. Strategi pembelajaran aktif permainan kartu tertempel pada siklus II telah selesai. Guru menutup pelajaran dengan menyimpulkan materi yang telah dipelajari sebelumnya. Pada akhir pelaksanaan tindakan siklus II, guru memberikan tes evaluasi siklus II untuk mengukur hasil belajar siswa. Hitung campuran nilai hasil belajar siswa siklus I dan siklus II dapat dilihat pada tabel berikut ini.

\section{Tabel 2. Hasil Belajar Siswa Siklus I dan II}

\begin{tabular}{|c|l|c|c|}
\hline No. & \multicolumn{1}{|c|}{ Hasil Tes } & Siklus I & Siklus II \\
\hline 1 & Jumlah Siswa Kelas VI & 24 & 24 \\
\hline 2 & Nilai Tertinggi & 92 & 100 \\
\hline 3 & Nilai Terendah & 64 & 70 \\
\hline 4 & Nilai Rata-rata & 76,50 & 84,83 \\
\hline 5 & Jumlah Siswa yang Tuntas & 19 & 24 \\
\hline 6 & Jumlah Siswa yang Tidak Tuntas & 5 & 0 \\
\hline 7 & Persentase Ketuntasan & $79,17 \%$ & $100 \%$ \\
\hline 8 & $\begin{array}{l}\text { Persentase Ketidak tuntasan } \\
\text { Belajar }\end{array}$ & $20,83 \%$ & $0 \%$ \\
\hline
\end{tabular}

Berdasarkan tabel di atas, diketahui adanya peningkatan hasil belajar sebelum tindakan pada akhir siklus II. Nilai rata-rata dari presentase ketuntasan belajar sudah meningkat dari data siklus I yaitu dari nilai rata-rata dan presentase ketuntasan belajar sudah meningkat dari data awal yaitu dari nilai rata- rata 76,50 menjadi 84,83 dan ketuntasan secara klasikal dari $79,17 \%$ menjadi $100 \%$. Ketuntasan belajar siklus IIsudah mencapai $100 \%$ sudah memenuhi kriteria indikator keberhasilan ketuntasan klasikal yang telah ditetapkan yaitu $85 \%$. 


\section{Pengamatan (Observing)}

Tahapan pengamatan, peneliti mengamati proses pembelajaran yang berlangsung dengan mencatat temuan-temuan yang ada pada lembar pengamatan yang telah tersedia. Ada dua aspek yang peneliti amati dalam proses pembelajaran Matematika dengan menggunakan strategi pembelajaran aktif permainan kartu tertempel yaitu aspek keaktifan siswa dan kinerja guru. Pada siklus II, keaktifan siswa dalam pembelajaran Matematika dengan menggunakan strategi pembelajaran aktif permainan kartu tertempel secara menyeluruh mencapai ratarata 83,97. Hal ini sudah memenuhi kriteria indikator keberhasilan ketuntasan klasikal yaitu 75\%. Berdasarkan hasil observasi dan dilakukan analisis data, maka diperoleh data bahwa pada siklus II secara keseluruhan tingkat keaktifan siswa sebesar 83,97 termasuk dalam kategori aktivitas baik. Selanjutnya pengamatan terhadap kinerja guru pada siklus II masih sama seperti pada siklus I. Pembelajaran Matematika dengan menggunakan strategi pembelajaran aktif permainan kartu tertempel pada siklus II termasuk kategori sangat baik karena mencapai $88,27 \%$.

\section{Refleksi}

Berdasarkan hasil pengamatan terhadap keaktifan siswa dan kinerja guru dalam pembelajaran Matematika menggunakan strategi pembelajaran aktif permainan kartu tertempel pada siklus II telah mangalami peningkatan. Pada siklus I peningkatan keaktifan siswa mencapai 67,31, sedangkan peningkatan keaktifan siswa pada siklus II menjadi 83,97. Demikian juga nilai tes evaluasi yang diperoleh siswa pada siklus II mengalami peningkatan.Pada siklus I nilai rata-rata kelas adalah 76,50 dengan ketuntasan klasikal 79,17\%. Pada siklus II nilai rata-rata kelas adalah 84,83 dengan ketuntasan belajar klasikal 100\%. Dengan demikian dapat disimpulkan bahwa pada siklus II keaktifan belajar, kinerja guru, dan hasil belajar Matematika sudaah memenuhi kriteria ketuntasan klasikal yang telah diterapkan yaitu $75 \%$ untuk keaktifan belajar dan $85 \%$ untuk ketuntasan belajar siswa.

\section{Pembahasan}

Pembahasan dalam PTK ini didasarkan pada hasil pengamatan yang dilanjutkan dengan kegiatan evaluasi dan refleksi. Berdasarkan hasil penelitian siklus I dan II menunjukkan bahwa pembelajaran Matematika dengan menggunakan strategi pembelajaran aktif permainan kartu tertempel mengalami peningkatan, baik dari segi peningkatan keaktifan siswa, kinerja guru, dan hasil belajar selama proses pembelajaran berlangsung. Strategi pembelajaran aktif permainan kartu tertempel berusaha mengoptimalkan aktifitas siswa. Hal ini dapat terlihat dalam langkah-langkah strategi pembelajaran aktif permainan kartu tertempel yang tercermin selama proses pembelajaran yang didominasi oleh aktifitas siswa. Pembelajaran dilakukan oleh siswa dengan cara mencocokan kartu yang berisi soal dan jawaban yang dibagi kepada teman sekelas yang berbeda beda (Permainan kartu tertempel) selanjutnya siswa mencari pasangan masing-masing untuk mencocokan jawaban mencari pasangan. Penggunakan strategi pembelajaran aktif permainan kartu tertempel dapat meningkatkan kerjasama siswa dalam memecahkan masalah dan memahami materi. Melalui permainan permainan kartu tertempel (kartu index), diharapkan siswa dapat memahami materi operasi hitung campuran. Strategi pembelajaran aktif permainan kartu tertempel juga mengajarkan ketrampilan sosial dan demokrasi. Dengan adanya penghargaan terhadap pasangan dengan kinerja terbaik, juga merupakan salah satu motivasi bagi siswa untuk meningkatkan aktivitas selama proses pembelajaran. Setiap pasangan bersaing untuk mendapatkan poin tertinggi dalam kelas, hal ini memotivasi siswa untuk berinteraksi dengan 
guru ataupun siswa lain dalam permainan permainan kartu tertempel (kartu index) sehingga siswa juga termotivasi untuk mempelajari dan memahami materi dengan baik.

Berdasarkan hasil pengamatan dan refleksi pada siklus 1 dapat diketahui bahwa pelaksanaan pembelajaran dengan strategi pembelajaran tersebut keterlibatan aktif siswa belum dapat berlangsung secara optimal dari hasil observasi pengamatan aktifitas siswa baru mencapai $70 \%$. Siswa masih merasa malu untuk bertanya dan takut dalam menjawab pertanyaan dari guru atau siswa lain sehingga lebih banyak siswa yang diam. Siswa juga belum bisa bekerjasama secara maksimal dalam diskusi dengan pasangannya serta belum memahami tata cara permainan permainan kartu tertempel (kartu index) pada saat pelaksanaan permainan meskipun secara keseluruhan siswa merasa senang dan semangat mengikuti pembelajaran ini. Aktifitas belajar yang kurang maksimal disebabkan karena siswa belum terbiasa dengan strategi pembelajaran aktif permainan kartu tertempelyang baru pertama baru pertama kali diterapkan pada pembelajaran Matematika dikelas VI SD Negeri 3 Mendenrejo. Dari latar belakang tersebut kemudian peneliti melanjutkan pembelajaran siklus II.

Dari hasil aktifitas siswa siklus II diperoleh presentase tingkat keaktifan siswa meningkat menjadi 83,97. Berdasarkan pengamatan pada siklus II siswa lebih aktif mengikuti proses pembelajaran dikelas, tidak malu lagi bertanya maupun menjawab pertanyaan dari guru atau siswa lain. Siswa telah mampu berdiskusi secara tertib dan baik. Siswa juga banyak berani menyampaikan maupun menanggapi hasil diskusi. Masing-masing pasangan ingin terlihat lebih menonjol dan mendapatkan nilai lebih baik. Pembelajaran yang dikombinasikan dengan permainan ini menciptakan suasana yang menyenangkan, siswa terlibat langsung dalam pembelajaran. Adanya pembelajaran ini menjadikan siswa merasa senang dan semangat dalam mengikuti proses pembelajaran. Melalui permainan ini siswa berusaha dengan bersungguh-sungguh untuk menemukan pasangan kartu yang mereka peroleh. Hal ini memotivasi siswa untuk berperan aktif dalam pembelajaran agar dapat memberikan hasil yang terbaik.

Hasil penilaian observasi kinerja guru sebelum menerapkan strategi pembelajaran aktif permainan kartu tertempel yakni sebesar 55,17\%. Selama proses pembelajaran siklus I guru terlihat masih canggung dalam menerapkan model pembelajaran tersebut. Kinerja guru pada siklus I mencapai $71,72 \%$, hal ini menunjukkan pembelajaran yang berlangsung termasuk dalam kriteria baik. Namun, hal ini perlu ditingkatkan lagi dengan perbaikan dalam siklus selanjutnya. Hal ini disebabkan kendala yang dihadapi pada saat pelaksanaan permainan yaitu suasana kelas menjadi ramai sehingga pengelolaan kelas yang baik sangat dibutuhkan. Oleh karena itu, guru harus mampu membimbing dan mengkondisikan siswa dengan lebih baik. Pada siklus II, hasil observasi kinerja guru menunjukkan peningkatan menjadi $88,27 \%$. Guru sudah lebih memahami dalam menerapkan strategi pembelajaran aktif permainan kartu tertempel yang telah dilaksanakan pada siklus I. Hasil observasi siklus II menunjukkan kinerja guru termasuk dalam kriteria sangat baik. Secara keseluruhan proses pembelajaran pada siklus I dan II berlangsung baik. Hal tersebut didukung oleh peningkatan aktivitas siswa dan kinerja guru sehingga berdampak pada meningkatnya hasil belajar siswa.

Hasil belajar tes evaluasi siklus I dapat diketahui adanya peningkatan dibanding sebelum dilaksanakan strategi pembelajaran aktif permainan kartu tertempel, tetapi ketuntasan belajar siklus I yang mencapai $79,17 \%$ belum memenuhi kriteria indikator keberhasilan ketuntasan klasikal yang telah ditetapkan yaitu 75\% siswa belajar tuntas sehingga perlu perbaikan pada siklus berikutnya. Hasil belajar tes evaluasi siswa diperoleh pada siklus II meningkat, hal ini dapat diketahui dari nilai rata-rata kelas siklus I sebesar 
76,50 meningkat menjadi 84,83. Persentase ketuntasan belajar juga meningkat dari persentase ketuntasan belajar pada siklus I sebesar 79,17\% meningkat menjadi $100 \%$ pada siklus II.

Peningkatan hasil belajar menggunakan strategi pembelajaran aktif permainan kartu tertempel juga diikuti tanggapan yang positif dari siswa terhadap strategi pembelajaran tersebut. Dalam kegiatan pembelajaran siswa tampak senang dan antusias mengikuti permainan. Berdasarkan hasil rekapitulasi dari hasil pengamatan dan data yang diperoleh selama penelitian menunjukkan bahwa penerapan strategi pembelajaran aktif permainan kartu tertempel dapat meningkatkan keaktifan belajar siswa kelas VI SD Inpres 3 Tolai.

\section{Kesimpulan}

Berdasarkan hasil penelitian ini dapat disimpulkan bahwa pembelajaran matematika melalui strategi pembelajaran permainan kartu tertempel dapat meningkatkan keaktifan belajar siswa kelas VI SD Inpres 3 Tolai. Bukti peningkatan keaktifan dan hasil belajar pada mata pelajaran Matematika tersebut, yaitu: (1) Peningkatan keaktifan siswa, rata-rata pra siklus 49,68. Pada siklus I mengalami peningkatan menjadi 67,31, dan siklus II mengalami peningkatan lagi menjadi 83,97; dan (2) Peningkatan hasil belajar siswa yang sudah memenuhi nilai ketuntasan, yaitu pra siklus sebesar 50\%. Pada siklus I mengalami peningkatan, yaitu menjadi 79,17\% dan meningkat lagi pada siklus II menjadi $100 \%$.

\section{Saran}

Adapun saran yang dapat disampaikan berdasarkan hasil penelitian ini antara lain adalah;

(1) Bagi Sekolah

Agar dapat mensosialisasikan strategi pembelajaran permainan kartu tertempel untuk meningkatkan keaktifan dan hasil belajar siswa.

(2) Bagi Guru

Strategi pembelajaran permainan kartu tertempel dapat digunakan sebagai salah satu alternatif dalam pembelajaran matematika untuk meningkatkan keaktifan siswa dan hasil belajar siswa pada mata pelajaran matematika yang menarik dan menyenangkan. Selalu memberikan sikap positif atau penghargaan kepada setiap aktivitas siswa pada proses pembelajaran matematika, karena dapat memicu siswa untuk selalu belajar giat sehingga memperoleh hasil belajar yang optimal serta mampu meningkatkan keberanian siswa dalam mengemukakan pendapat saat proses pembelajaran maupun kerja kelompok.

(3) Bagi Siswa

Diharapkan setelah penelitian ini selesai dilaksanakan, siswa lebih aktif dan berani untuk bertanya dan mengungkapkan pendapat setelah mengetahui dan memahami strategi pembelajaran permainan kartu tertempel dan lebih konsentrasi dan fokus pada waktu proses pembelajaran berlangsung.

\section{Daftar Pustaka}

Arikunto, Suharsimi. (2009). Penelitian Tindakan Kelas. Jakarta: Bumi Aksara. Daryanto. (2010). Media pembelajaran. Yogyakarta : Gava Media

Irni, H. (2016). Pemanfaatan Bahan Sederhana Menjadi Alat Peraga Keranjang Faktor untuk Meningkatkan Hasil Belajar Matematika Materi FPB dan KPK pada Siswa Kelas V SDN 10 Mataram. Jurnal Kependidikan: Jurnal Hasil Penelitian dan Kajian Kepustakaan di Bidang Pendidikan, Pengajaran dan Pembelajaran, 2(2). doi:https://doi.org/10.33394/jk.v2i2.453 
Nurhayati, E. (2020). Meningkatkan Keaktifan Siswa Dalam Pembelajaran Daring Melalui Media Game Edukasi Quiziz pada Masa Pencegahan Penyebaran Covid-19. Jurnal Paedagogy, 7(3), 145-150. doi:https://doi.org/10.33394/jp.v7i3.2645

Sanjaya, Wina. (2006). Strategi Pembelajaran Beroriantasi Standar Proses Pendidikan. Jakarta: Kencana Prenada Media.

Sardiman. (2007). Interaksi dan Motivasi Belajar Mengajar. Jakarta: Raja Grafindo Persada.

Selamet, I. (2020). Penggunaan Media Visual untuk Meningkatkan Hasil Belajar Mata Pelajaran IPS Siswa Kelas V SD Inpres Tumpu Jaya I. Jurnal Paedagogy, 7(2), 121-125. doi:https://doi.org/10.33394/jp.v7i2.2505

Silbermen, Melvin. (2009). Active Learning 101 Strategi Pembelajaran Aktif. Yogyakarta: Pustaka Insan Madani.

Slameto. (2010). Belajar dan Faktor-faktor yang Mempengaruhinya. Jakarta: Rineka Cipta.

Suarni, G., Rizka, M., \& Zinnurain, Z. (2021). Analisis Pengaruh Penerapan Model Pembelajaran Sains Teknologi Masyarakat Terhadap Hasil Belajar Siswa. Jurnal Paedagogy, 8(1), 31-38. doi:https://doi.org/10.33394/jp.v8i1.3226

Suharni, S. (2021). Meningkatkan Keaktifan dan Hasil Belajar Melalui Penerapan Model Pembelajaran Wide Game pada Peserta Didik Kelas VIID SMP Negeri 13 Tegal. Jurnal Paedagogy, 8(1), 87-92. doi:https://doi.org/10.33394/jp.v8i1.3278

Suprijono, Agus. (2011). Cooperative Learning: Teori dan Aplikasi PAIKEM. Yogyakarta: Pustaka Belajar.

Yuliati, G. (2018). Peningkatan Hasil Belajar Matematika Siswa Kelas XI IPA 3 SMA Negeri 1 Batukliang Melalui Penggunaan Model Pembelajaran Student Teams Achievement Division. Jurnal Kependidikan: Jurnal Hasil Penelitian dan Kajian Kepustakaan di Bidang Pendidikan, Pengajaran dan Pembelajaran, 4(1), 31-40. doi:https://doi.org/10.33394/jk.v4i1.899

Zainuri, K. (2020). Peningkatan Hasil Pembelajaran Lompat Jauh Melalui Pendekatan Bermain Longu pada Siswa Kelas IV SDN 37 Ampenan. Jurnal Paedagogy, 7(1), 35-42. doi:https://doi.org/10.33394/jp.v7i1.2513 